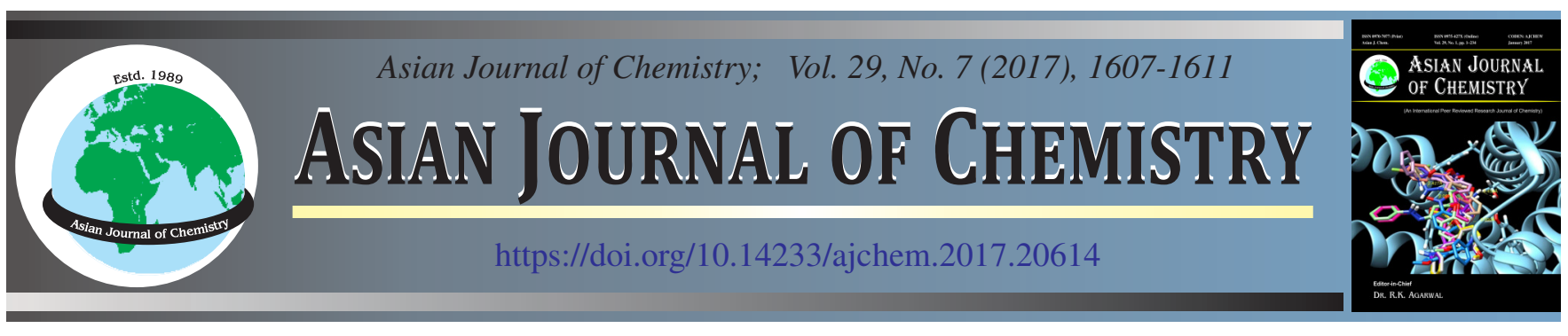

\title{
Study of Degradation Behaviour of Alogliptin Benzoate by Stability Indicating High Performance Thin Layer Chromatographic Method
}

\author{
Jasmina Shivlal Surati ${ }^{1, *}$ and Vandana B. Patel ${ }^{2}$
}

\begin{abstract}
${ }^{1}$ Department of Quality Assurance, Shree Naranjibhai Lalbhai Patel College of Pharmacy, Umrakh-394 345, India
\end{abstract}
${ }^{2}$ Babaria Institute of Pharmacy, Vadodara-391 240, India

*Corresponding author: E-mail: j.s.surati@gmail.com

\begin{abstract}
A simple, selective, precise, rapid and accurate stability indicating HPTLC method was developed and validated for estimation of alogliptin benzoate in tablet dosage form. In this work, alogliptin was estimated using $n$-butanol:water:acetic acid (7:2:1 v/v/v) as mobile phase and aluminium backed TLC plates pre-coated with $250 \mu \mathrm{m}$ layer of silica gel $60 \mathrm{~F}_{254}$ as stationary phase. The detection carried out at $233 \mathrm{~nm}$. The linearity range was found to be $200-600 \mathrm{ng} / \mathrm{spot}\left(\mathrm{r}^{2}=0.9941\right)$. Validation of developed method was performed as per ICH guidelines. Stress testing of alogliptin was performed under acidic, alkaline, oxidative, photolytic and dry heat degradation conditions. The chromatographic conditions successfully resolved alogliptin from its degradation products, formed under various stress conditions. Alogliptin was not significantly degraded in oxidative, photolytic and dry heat degradation conditions and is prone to acidic and alkaline hydrolysis. Tablet dosage form of alogliptin was analyzed by the developed method.
\end{abstract}

Keywords: Degradation study, Alogliptin benzoate, HPTLC method.

\section{INTRODUCTION}

Alogliptin benzoate (ALO) is a selective and orally administered antidiabetic drug belongs to dipeptidyl peptidase-4 (DPP4) inhibitors class. Dipeptidyl peptidase-4 inhibitors is a new therapeutic approach that stimulate glucose dependent insulin secretion and reduces glucagon level. The mechanism behind this is to increase incretin levels, particularly gastric inhibitory polypeptide (GIP) and glucagon-like peptide-1 (GLP-1) [1]. The chemical name of alogliptin benzoate is 2-[[6-[(3R)-3amino-1-piperidinyl]-3,4-dihydro-3-methyl-2,4-dioxo-1(2H)pyrimidinyl]methyl]benzonitrile monobenzoate and the chemical structure of alogliptin benzoate is shown in Fig. 1 [2].

From literature survey, it was found that, analytical methods like UV and HPLC have been reported for estimation of alogliptin benzoate in dosage form [3-6]. Reported methods describe estimation of alogliptin benzoate alone and in combination with other drugs [7-17]. Among them two methods are stability indicating methods, in which limited stress conditions were applied.

Now a days in analytical laboratories, there is always requirement for significant stability-indicating methods (SIMs) of analysis. Environmental factors, such as $\mathrm{pH}$, temperature, light, oxygen, humidity, buffer species, ionic strength, additives<smiles>Cn1c(=O)cc(N2CCC[C@@H](N)C2)n(Cc2ccccc2C#N)c1=O</smiles>

Fig. 1. Chemical structure of alogliptin benzoate

and excipients, can play a vital role in the stability of drug substances. Stress testing can be helpful in identification of degradation products and can provide important information regarding stability of drug substances [18]. With the advent of the International Conference on Harmonization (ICH) guidelines [19], requirements for the establishment of SIMs have become more vital. The scientific novelty of the present work is that degradation behaviour of alogliptin benzoate in various stress condition has been explored using HPTLC method. 


\section{EXPERIMENTAL}

Alogliptin benzoate was procured from Swapnroop Chemicals, Maharashtra, India. Acetic acid, n-butanol, hydrochloric acid and sodium hydroxide were purchased from S.D. Fine-Chem Limited, Mumbai, India.

The HPTLC system (Camag, Switzerland) equipped with Linomat V semiautomatic sample applicator, Camag twintrough developing chamber $(10 \times 10 \mathrm{~cm})$, UV chamber with dual wavelength UV lamps, TLC Scanner IV (Camag Muttenz, Switzerland), Hamilton syringe (100 $\mu$ L capacity), winCATS software (version 1.4.6.2002) and aluminium backed TLC plates $(10 \times 10 \mathrm{~cm})$ precoated with $250 \mu \mathrm{m}$ layer of silica gel $60 \mathrm{~F}_{254}$ (E. Merk, Darmstsdt, Germany) were used for chromatographic method development. For weighing purpose, Electronic analytical balance (Shimadzu AUW-220) was used. Hot air oven (Micro Scientific Ltd.) and controlled temperature water bath (Durga Scientific Equipment) were used for degradation study of alogliptin benzoate.

Final chromatographic conditions: Before sample application the TLC plates were washed with methanol and dried for $10 \mathrm{~min}$ in oven at $50{ }^{\circ} \mathrm{C}$. The sample application was done with Linomat $\mathrm{V}$ semi-automatic sample applicator on prewashed TLC plates, $15 \mathrm{~mm}$ from bottom edge of plates. The sample application rate was $100 \mathrm{nl} / \mathrm{s}$ and band width was $6 \mathrm{~mm}$.

For chromatographic resolution of alogliptin, twin trough developing chamber was saturated with $n$-butanol:water:acetic acid $(7: 2: 1, \mathrm{v} / \mathrm{v} / \mathrm{v})$ mobile phase at $25 \pm 2{ }^{\circ} \mathrm{C}$ and relative humidity $35 \pm 5 \%$. The chamber saturation time was $15 \mathrm{~min}$ and development distance was $80 \mathrm{~mm}$. After development the TLC plates were dried and scanned by TLC Scanner IV at $233 \mathrm{~nm}$. The scanning speed was $20 \mathrm{~mm} / \mathrm{sec}$ and slit dimension was. $6 \times$ $0.45 \mathrm{~mm}$. The data analysis was done by slit dimension, $6 \times$ $0.45 \mathrm{~mm}$ and all the developments were operated by winCATS software (version 1.4.6).

\section{Preparation of solutions}

Preparation of standard solution of alogliptin benzoate: Accurately weighed $10 \mathrm{mg}$ alogliptin benzoate was transferred to $10 \mathrm{~mL}$ volumetric flask and dissolved in methanol to get stock solution having strength of $1000 \mu \mathrm{g} / \mathrm{mL}$. The standard stock solution of alogliptin benzoate was further diluted with methanol to get working standard solution $(20 \mu \mathrm{g} / \mathrm{mL})$.

Preparation of sample solutions for forced degradation study of alogliptin benzoate: Alogliptin benzoate was exposed to acidic, alkaline, oxidative, photolytic and dry heat degradation conditions for forced degradation study.

Acidic and alkaline hydrolysis: $1 \mathrm{~mL}$ stock solution (1000 $\mu \mathrm{g} / \mathrm{mL}$ ) of alogliptin benzoate was transferred to each two 10 $\mathrm{mL}$ volumetric flasks and $5 \mathrm{~mL}$ of $1 \mathrm{~N} \mathrm{HCl}$ and $1 \mathrm{~N} \mathrm{NaOH}$ were added separately. These solutions were kept in a water bath at 60 ${ }^{\circ} \mathrm{C}$ for $2 \mathrm{~h}$, cooled to room temperature and diluted up to the mark with methanol. Further, from each solution aliquot of 2 $\mathrm{mL}$ was withdrawn and transferred into $10 \mathrm{~mL}$ volumetric flasks. The stressed samples were neutralized with $1 \mathrm{~N} \mathrm{NaOH}$ or $1 \mathrm{~N}$ $\mathrm{HCl}$, respectively and diluted up to mark with methanol to furnish final concentration of $20 \mu \mathrm{g} / \mathrm{mL}$.

Oxidative degradation: $1 \mathrm{~mL}$ stock solution $(1000 \mu \mathrm{g} / \mathrm{mL})$ of alogliptin benzoate was transferred to $10 \mathrm{~mL}$ volumetric flask and $5 \mathrm{~mL}$ of $3 \% \mathrm{H}_{2} \mathrm{O}_{2}$ was added. This solution was kept in a water bath at $70{ }^{\circ} \mathrm{C}$ for $1 \mathrm{~h}$, cooled to room temperature and diluted up to the mark with methanol. Further, aliquot of $2 \mathrm{~mL}$ was withdrawn from above solution and transferred into $10 \mathrm{~mL}$ volumetric flask and diluted up to mark with methanol to get concentration of $20 \mu \mathrm{g} / \mathrm{mL}$.

Photolytic degradation: $15 \mathrm{mg}$ of pure alogliptin benzoate sample was exposed to sunlight for $24 \mathrm{~h}$. From this, accurately weighed $10 \mathrm{mg}$ of alogliptin benzoate was transferred to $10 \mathrm{~mL}$ volumetric flasks and dissolved in methanol. Further, $1 \mathrm{~mL}$ was withdrawn and diluted to $10 \mathrm{~mL}$ with methanol to obtain concentration of $100 \mu \mathrm{g} / \mathrm{mL}$. From resulted solution, aliquot of $2 \mathrm{~mL}$ was diluted to $10 \mathrm{~mL}$ with methanol to get concentration of $20 \mu \mathrm{g} / \mathrm{mL}$.

Dry heat degradation: $15 \mathrm{mg}$ of pure alogliptin benzoate was placed in the china dish and kept into the oven at $80{ }^{\circ} \mathrm{C}$ for $6 \mathrm{~h}$. The powder was allowed to cool to room temperature and accurately weighed $10 \mathrm{mg}$ of alogliptin benzoate was transferred to $10 \mathrm{~mL}$ volumetric flasks and dissolved in methanol. Aliquot of $1 \mathrm{~mL}$ was appropriately diluted with methanol to obtain concentration of $100 \mu \mathrm{g} / \mathrm{mL}$. From resulted solution, aliquot of $2 \mathrm{~mL}$ was diluted to $10 \mathrm{~mL}$ with methanol to get concentration of $20 \mu \mathrm{g} / \mathrm{mL}$.

Preparation of calibration curve: From working standard solution of alogliptin benzoate $(20 \mu \mathrm{g} / \mathrm{mL})$, aliquots of 10,15 , 20,25 and $30 \mu \mathrm{L}$ were applied on a TLC plate with micro syringe using Linomat $\mathrm{V}$ semi-automatic sample applicator to get final concentration of 200-600 ng/spot. The plate was developed in twin trough chamber, dried and analyzed according to optimized chromatographic conditions. Calibration curve was established by plotting peak area of alogliptin benzoate against corresponding alogliptin benzoate concentration.

Analysis of forced degradation samples of alogliptin benzoate: From each stress condition, $20 \mu \mathrm{L}$ of degraded sample solutions was spotted on TLC plate to get $400 \mathrm{ng} / \mathrm{spot}$. The plate was developed in twin trough chamber, dried and analyzed according to optimized chromatographic conditions.

Analysis of alogliptin in tablet dosage form: For the determination of alogliptin in tablet dosage form, 20 tablets were accurately weighed and powdered. Powder equivalent to $10 \mathrm{mg}$ was taken in to $10 \mathrm{~mL}$ volumetric flasks and dissolved in $5 \mathrm{~mL}$ of methanol. The solution was sonicated for $10 \mathrm{~min}$ and volume was made up to the mark with the methanol. The resulting solution was filtered through Whatman filter No. 41 and aliquot of $1 \mathrm{~mL}$ was appropriately diluted with methanol to obtain concentration of $100 \mu \mathrm{g} / \mathrm{mL}$. Further, $2 \mathrm{~mL}$ from above solution was transferred into $10 \mathrm{~mL}$ volumetric flask and diluted up to mark with methanol to get concentration of $20 \mu \mathrm{g} / \mathrm{mL}$. Three replicates were obtained in same manner and $20 \mu \mathrm{L}$ from each solution was spotted on TLC plate. The plate was developed in twin trough chamber, dried and analyzed according to optimized chromatographic conditions.

\section{RESULTS AND DISCUSSION}

Optimization of mobile phase: Drug solution and stressed solutions from different degradation conditions were applied on the TLC plates and were run in single solvents as well as in mixture of solvents or modifiers. Final optimized mobile phase 
consisted of $n$-butanol:water:acetic acid in ratio of 7:2:1 (v/v/v) that gave good resolution and can separate all the degradation products of alogliptin benzoate in different stress conditions. $\mathrm{R}_{\mathrm{f}}$ value of alogliptin benzoate in this mobile phase composition is 0.53 .

Selection of wavelength of detection: UV spectra obtained by scanning spot of alogliptin benzoate between 200 to $700 \mathrm{~nm}$ showed maximum absorbance of respective spot at $233 \mathrm{~nm}$ hence it was selected as wavelength for estimation of alogliptin benzoate.

Calibration curves: Calibration curve of alogliptin benzoate was prepared in the range of 200-600 ng/spot $(n=5)$. They were found to be linear in the above concentration range. Chromatogram and calibration curve of alogliptin benzoate is shown in Figs. 2 and 3, respectively.

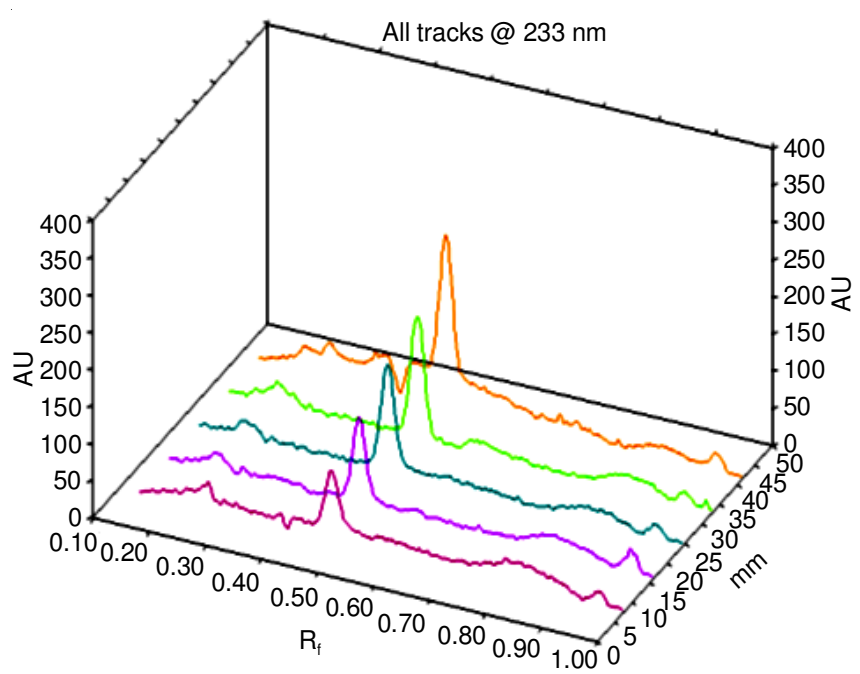

Fig. 2. 3D Chromatogram of different concentrations of alogliptin (200$600 \mathrm{ng} / \mathrm{band})$

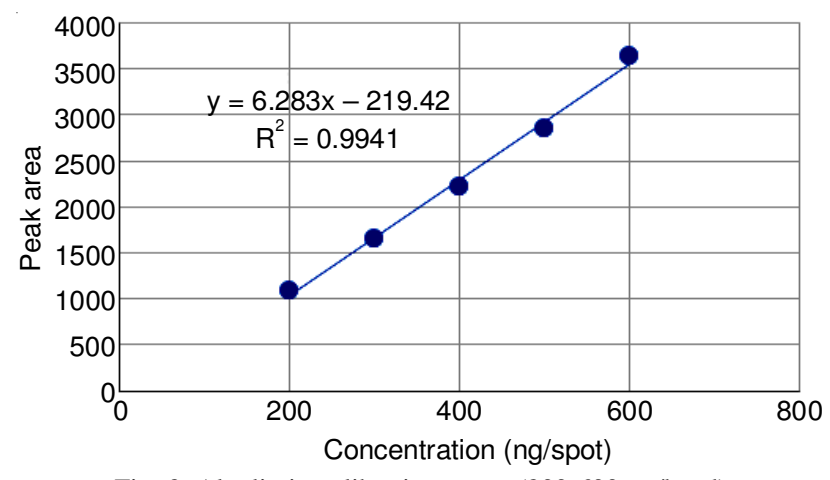

Fig. 3. Alogliptin calibration curve (200-600 ng/band)

Validation of developed method: To confirm the suitability of the method for its intended purpose, it was validated in accordance with ICH guidelines [20].

Linearity and range: Linearity of alogliptin benzoate was studied by plotting mean peak area of alogliptin benzoate against concentrations over the range of 200-600 ng/spot ( $\mathrm{n}=$ 3) (Fig. 3). Linear regression data are shown in Table-1.

\section{Precision}

Repeatability of measurement and repeatability of sample application: Instrument precision was checked by

\begin{tabular}{ll}
\multicolumn{2}{c}{ TABLE-1 } \\
REGRESSION ANALYSIS OF ALOGLIPTIN \\
\hline Parameter & Result \\
\hline Straight line equation & $\mathrm{y}=6.283 \mathrm{x}-219.42$ \\
Correlation co-efficient $\left(\mathrm{r}^{2}\right)$ & 0.9941 \\
\hline
\end{tabular}

repeated scanning of the same spot (200 ng/spot) seven times without changing the plate position. Results of this determination are shown in Table-2.

TABLE-2

REPEATABILITY DATA OF ALOGLIPTIN BENZOATE

\begin{tabular}{ccc}
$\begin{array}{c}\text { Concentration of } \\
\text { alogliptin benzoate } \\
\text { (ng/spot) }\end{array}$ & $\begin{array}{c}\text { Repeatability of } \\
\text { measurement peak } \\
\text { area-alogliptin } \\
\text { benzoate }\end{array}$ & $\begin{array}{c}\text { Repeatability of } \\
\text { sample application } \\
\text { peak area-alogliptin } \\
\text { benzoate }\end{array}$ \\
\hline 200 & 1097 & 1097 \\
200 & 1088 & 1098 \\
200 & 1063 & 1076 \\
200 & 1068 & 1088 \\
200 & 1081 & 1062 \\
200 & 1093 & 1085 \\
200 & 1054 & 1092 \\
Mean & 1077.71 & 1085.42 \\
SD & 16.30 & 12.77 \\
$\%$ RSD & 1.51 & 1.17 \\
\hline
\end{tabular}

Intermediate precision: Intra-day precision of developed method was checked by analyzing three different concentrations (300, 400 and $500 \mathrm{ng} / \mathrm{spot}$ ), three times on different time interval of same day. Inter-day precision of developed method was checked by analyzing three different concentrations (300, 400 and $500 \mathrm{ng} / \mathrm{spot}$ ), three times on three different days. Results of intermediate precision are summarized in Table-3.

\begin{tabular}{|c|c|c|c|c|}
\hline \multicolumn{5}{|c|}{$\begin{array}{c}\text { TABLE-3 } \\
\text { INTERMEDIATE PRECISION DATA } \\
\text { FOR ALOGLIPTIN BENZOATE }\end{array}$} \\
\hline \multirow{2}{*}{$\begin{array}{l}\text { Conc. } \\
\text { (ng/spot) }\end{array}$} & \multicolumn{2}{|c|}{ Intra-day precision } & \multicolumn{2}{|c|}{ Inter-day precision } \\
\hline & $\begin{array}{l}\text { Area }(\text { Mean } \pm \\
\text { SD) }(n=3)\end{array}$ & $\begin{array}{l}\mathrm{RSD} \\
(\%)\end{array}$ & $\begin{array}{l}\text { Area }(\text { Mean } \pm \\
\text { SD) }(n=3)\end{array}$ & $\begin{array}{l}\text { RSD } \\
(\%)\end{array}$ \\
\hline 300 & $1655.00 \pm 14.73$ & 0.89 & $1677.33 \pm 19.50$ & 1.16 \\
\hline 400 & $2240.63 \pm 21.58$ & 0.96 & $2255.63 \pm 27.70$ & 1.23 \\
\hline 500 & $2878.33 \pm 33.50$ & 1.16 & $2855.67 \pm 38.13$ & 1.34 \\
\hline
\end{tabular}

Accuracy (recovery study): Accuracy of proposed method was determined by recovery studies from tablet dosage form at three levels (80,100 and $120 \%)$ of standard addition. These results of recovery studies are given in Table-4.

TABLE-4

RECOVERY STUDY DATA FOR ALOGLIPTIN BENZOATE

\begin{tabular}{ccccc}
\hline $\begin{array}{c}\text { Alogliptin } \\
\text { from tablet } \\
\text { dosage } \\
\text { form } \\
\text { (ng/spot) }\end{array}$ & $\begin{array}{c}\text { Spiked } \\
\text { amount of } \\
\text { standard } \\
\text { alogliptin } \\
\text { (ng/spot) }\end{array}$ & $\begin{array}{c}\text { Total } \\
\text { amount of } \\
\text { alogliptin } \\
(\text { ng/spot })\end{array}$ & $\begin{array}{c}\text { Amount } \\
\text { recovered } \\
(\text { mean } \pm \text { SD }) \\
(\mathrm{n}=3)\end{array}$ & $\begin{array}{c}\text { Mean \% } \\
\text { recovery }\end{array}$ \\
\hline 200 & - & 200 & - & - \\
200 & 160 & 360 & $159.60 \pm 1.73$ & 99.75 \\
200 & 200 & 400 & $203.28 \pm 2.40$ & 101.64 \\
200 & 240 & 440 & $237.70 \pm 2.40$ & 99.04 \\
\hline
\end{tabular}




\section{Sensitivity [limit of detection (LOD) and limit of quan-} tification (LOQ)]: Sensitivity of proposed method was determined in term of LOD and LOQ. The LOD and LOQ for alogliptin benzoate were found to be 25.34 and $76.78 \mathrm{ng} / \mathrm{spot}$, respectively. The validation summary is depicted in Table-5.

\begin{tabular}{lc}
\multicolumn{2}{c}{ TABLE-5 } \\
\multicolumn{2}{c}{ SUMMARY OF VALIDATION PARAMETERS } \\
\hline Parameters & Results \\
\hline Linearity range & 200-600 $\mathrm{ng} / \mathrm{spot}$ \\
Regression line equation & $6.257 \mathrm{x}-209.61$ \\
Correlation co-efficient $\left(\mathrm{R}^{2}\right)$ & 0.9941 \\
Precision (\% RSD) & \\
Repeatability of measurement $(\mathrm{n}=7)$ & 1.51 \\
Repeatability of sample application $(\mathrm{n}=7)$ & 1.17 \\
Intra-day precision $(\mathrm{n}=3)$ & $0.89-1.16$ \\
Inter-day precision $(\mathrm{n}=3)$ & $1.16-1.33$ \\
$\%$ Recovery(n $=3)$ & $99.04-101.64$ \\
Limit of detection $(\mathrm{LOD})(\mathrm{ng} / \mathrm{spot})$ & 25.34 \\
Limit of quantitation $(\mathrm{LOQ})(\mathrm{ng} / \mathrm{spot})$ & 76.78 \\
\hline
\end{tabular}

Analysis of forced degradation samples of alogliptin benzoate: There were no significant reduction in peak areas of samples of alogliptin benzoate exposed to oxidative degradation, dry heat degradation and photolytic degradation conditions as compared to standard alogliptin benzoate. Alogliptin benzoate was found to be degraded in acid hydrolysis and alkaline hydrolysis conditions. Findings of degradation study is reported in Table-6. Densitograms of alogliptin benzoate degradation in acid hydrolysis and alkaline hydrolysis conditions is shown in Figs. 4 and 5, respectively. While the densitograms of alogliptin benzoate degradation in oxidative, photolytic and heat degradation conditions is shown in Figs. 6-8, respectively.

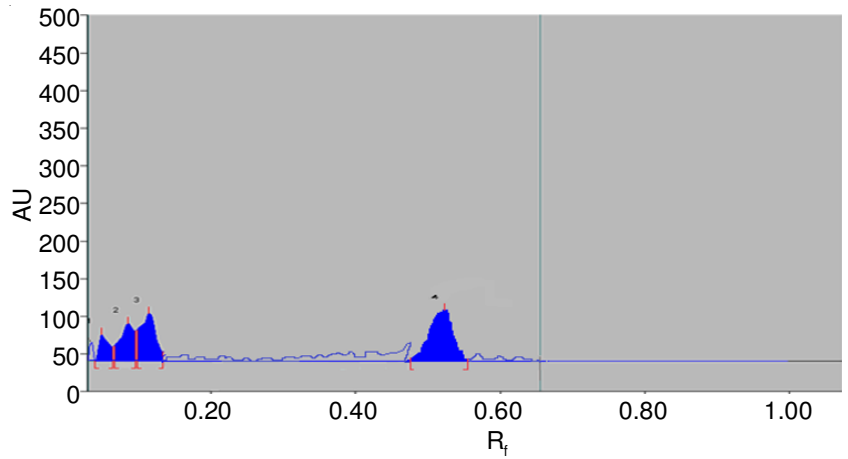

Fig. 4. Densitogram of acid induced degradation study; Condition: $1 \mathrm{~N} \mathrm{HCl}$ at $60{ }^{\circ} \mathrm{C}$ for $2 \mathrm{~h}$

Assay of alogliptin in tablet dosage form: The percentage assay was calculated from label claim and data are shown in Table-7.

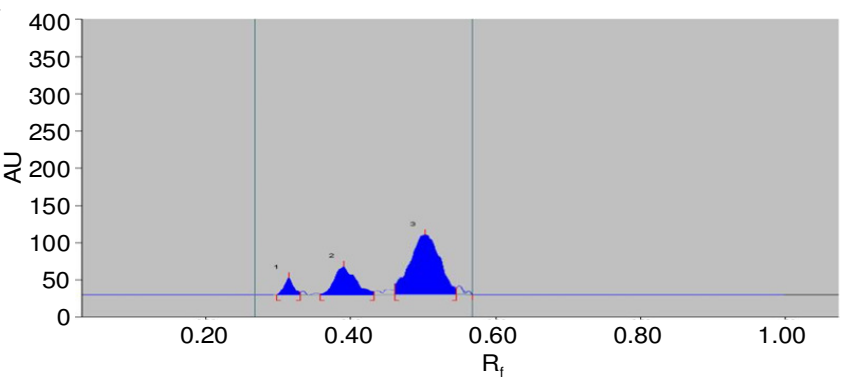

Fig. 5. Densitogram of alkali induced degradation study; Condition: $1 \mathrm{~N}$ $\mathrm{NaOH}$ at $60{ }^{\circ} \mathrm{C}$ for $2 \mathrm{~h}$

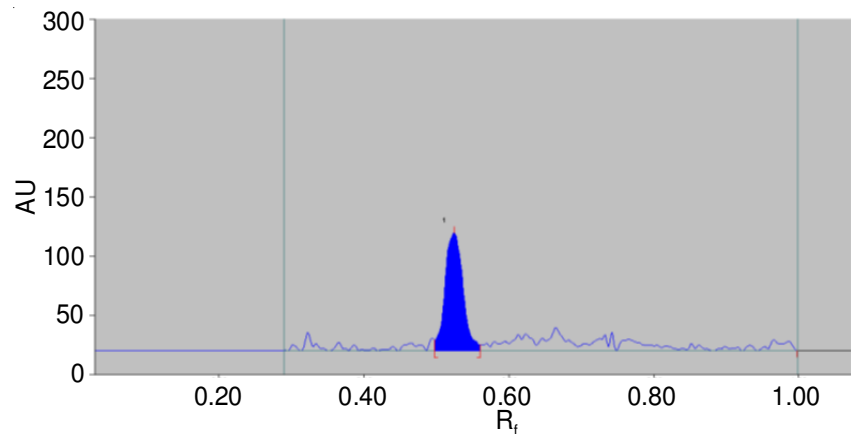

Fig. 6. Densitogram of oxidative induced degradation study; Condition: 3 $\% \mathrm{H}_{2} \mathrm{O}_{2}$ at $60{ }^{\circ} \mathrm{C}$ for $1 \mathrm{~h}$

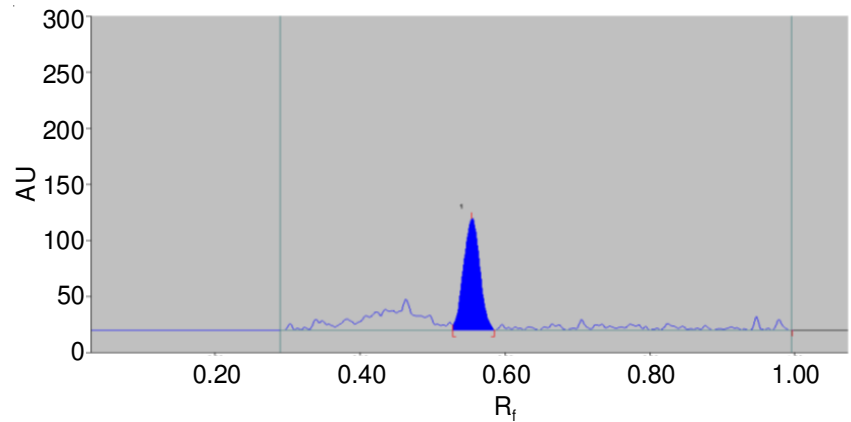

Fig. 7. Densitogram of photolytic degradation study; Condition: drug solution is directly exposed to sunlight for $24 \mathrm{~h}$

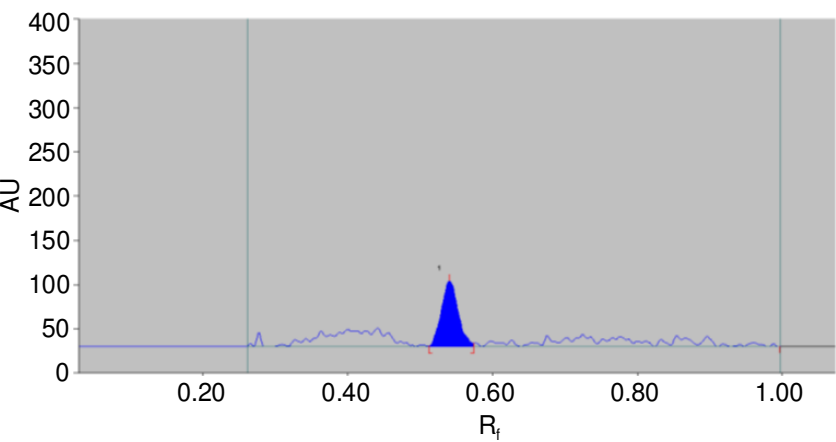

Fig. 8. Densitogram of dry heat degradation study; Condition: In oven at $80{ }^{\circ} \mathrm{C}$ for $6 \mathrm{~h}$

TABLE-6

SUMMARY OF DEGRADATION PRODUCTS OF ALOGLIPTIN IN VARIOUS STRESS CONDITIONS

\begin{tabular}{llccc}
\hline \multicolumn{1}{c}{$\begin{array}{c}\text { Force degradation } \\
\text { condition }\end{array}$} & \multicolumn{1}{c}{ Stress condition } & $\mathrm{R}_{\mathrm{f}}$ value of degradants & $\begin{array}{c}\text { Alogliptin remaining } \\
\text { undergraded }(\%)\end{array}$ & Degradation (\%) \\
\hline Acidic degradation & $\left(1 \mathrm{~N} \mathrm{HCl} / 60^{\circ} \mathrm{C} / 2 \mathrm{~h}\right)$ & $0.05,0.09,0.11$ & 80.95 & 19.05 \\
Alkaline degradation & $\left(1 \mathrm{~N} \mathrm{NaOH} / 60^{\circ} \mathrm{C} / 2 \mathrm{~h}\right)$ & $0.31,0.39$ & 73.79 & 26.21 \\
Oxidative degradation & $\left(3 \% \mathrm{v} / \mathrm{v} \mathrm{H}_{2} \mathrm{O}_{2} / 70{ }^{\circ} \mathrm{C} / 1 \mathrm{~h}\right)$ & - & 96.47 & 3.53 \\
Photo degradation & $24 \mathrm{~h} \mathrm{in} \mathrm{sunlight}$ & - & 97.66 & 2.34 \\
Thermal degradation & $\left(80^{\circ} \mathrm{C} / 6 \mathrm{~h}\right)$ & - & 96.71 & 3.29 \\
\hline
\end{tabular}




\begin{tabular}{ccccc}
\hline \multicolumn{5}{c}{ TABLE-7 } \\
ASSAY OF ALOGLIPTIN IN TABLET DOSAGE FORM \\
\hline Component & $\begin{array}{c}\text { Powder } \\
\text { taken }(\mathrm{mg})\end{array}$ & $\begin{array}{c}\text { Amount found } \\
(\text { mean } \pm \text { SD }) \\
(\mathrm{n}=3)\end{array}$ & $\begin{array}{c}\text { Assay } \\
(\%)\end{array}$ & $\begin{array}{c}\text { RSD } \\
(\%)\end{array}$ \\
\hline Alogliptin & 10 & $9.94 \pm 1.22$ & 99.35 & 0.31 \\
\hline
\end{tabular}

\section{Conclusion}

A stability-indicating HPTLC method has been developed and validated for the quantitative estimation of alogliptin benzoate in bulk drug and tablet dosage form. The developed method is able to separate all the degradation products formed under different of stress conditions. The overall results confirm the method to be precise, specific, selective, accurate, robust and stability indicating for analysis of alogliptin benzoate. Stress testing finds alogliptin benzoate to be degraded in acid and alkaline hydrolysis conditions. Hence, this method can be recommended for routine analysis of the alogliptin and its degradation products in stability samples.

\section{REFERENCES}

1. R. Christopher and A. Karim, Clin. Pharmacol., 2, 589 (2009); https://doi.org/10.1586/ecp.09.45.

2. R.I. El-Bagary, E.F. Elkady and B.M. Ayoub, Int. J. Biomed. Sci., 8, 215 (2012).

3. K. Zhang, P. Ma, W. Jing and X. Zhang, Asian J. Pharm. Sci., 10, 152 (2015);

https://doi.org/10.1016/j.ajps.2015.01.001.
4. Y. Zhou, W. Zhou, L. Sun, Q.G. Zou, P. Wei and P.K. OuYang, J. Sep. Sci., 37, 1248 (2014); https://doi.org/10.1002/jssc. 201301384.

5. P.J. Yadav, V.N. Kadam and S.K. Mohite, J. Curr. Pharm. Res., 4, 1286 (2014).

6. G.S. Sri, S.A. Kumar, J. Saravanan, M. Debnath, V. Greeshma and N.S. Krishna, Indo Am. J. Pharm. Res., 3, 9222 (2013).

7. A.P. Kumar, G. Aruna, K. Rajasekar and P.J. Reddy, Int. Bull. Drug Res., 3, 58 (2013).

8. K. Swathi, Int. J. Pharm. Res. Health Sci., 3, 747 (2015).

9. M. Anusha, A. Manzoor, S.A. Satishkumar and K.C.A. Vijaya, Int. J. Uni. Pharm. Bio. Sci., 3, 363 (2014).

10. K. Raval and U. Srinivasa, Pharm., 5, 56 (2015).

11. K. Raval and U. Srinivasa, Int. J. Curr. Res., 6, 10201 (2014).

12. K. Raval and U. Srinivasa, Int. J. Pharm. Pharm. Sci., 6, 730 (2014).

13. D.B. Sen, A.K. Sen, A. Zanwar, R. Balaraman and A.K. Seth, Int. J. Pharm. Pharm. Sci., 7, 380 (2015).

14. S.C. Daswadkar, M.A. Roy, S.G. Walode and C.B. Mahendra Kumar, Int. J. Chem. Sci., 14, 649 (2016).

15. C. Parle and A. Parle, Pharmachem., 6, 303 (2014).

16. K. Sharma, A. Parle and S. Ahmad, Der Pharm. Lett., 7, 321 (2015).

17. K.S. Ashutosh, D. Manidipa, R.J.V.L.N. Seshagiri and S.D. Gowri, J. Chromatogr. Sep. Tech., 6, 293 (2015); https://doi.org/10.4172/2157-7064.1000293.

18. S. Singh and M. Bakshi, Pharm. Tech., 24, 1 (2000).

19. Stability Testing of New Drug Substances and Products, In: International Conference on Harmonization of Technical Requirements for Registration of Pharmaceutical for Human Use, Q1A (R2) (2003).

20. Validation of Analytical Procedures: Text and Methodology, In: International Conference on Harmonization of Technical Requirements for Registration of Pharmaceutical for Human Use, Q2 (R1) (2005). 